\title{
Capsaicin potently blocks Salmonella typhimurium invasion of Vero cells
}

\section{Joseph A. Ayariga1*, Daniel A. Abugri', Balagopal Amrutha ${ }^{3}$, Robert Villafane ${ }^{4}$}

1 The Biomedical Engineering Program, College of Science, Technology, Engineering and Mathematics (C-STEM), Alabama State University, 1627 Hall Street, Montgomery, AL, 36104.

${ }^{2}$ Microbiology PhD Program, Laboratory of Ethnomedicine, Parasitology, and Drug Discovery, College of Science, Technology, Engineering and Mathematics, ${ }^{5}$ Biomedical Engineering Program, Alabama State University, Montgomery, AL, 36104, USA.

${ }^{3}$ Division of Oncology, College of Medicine, University of Saskatchewan, Saskatoon, SK S7N 5E5, Canada.

4 Department of Biological Sciences, College of Science, Technology, Engineering and Mathematics (C-STEM), Alabama State University, 1627 Hall Street Montgomery, Alabama 36104.

*Correspondence: jayariga7546@myasu.alasu.edu

\begin{abstract}
As at 2021, the center for disease control (CDC) reported that Salmonella causes 1.2 million illness in the United States each year, with a mortality rate approaching 500 deaths per annum. Infants, the elderly, and persons with compromised immunity are the population with higher risk of mortality from this infection. At present there is no commercially available, safe and efficacious vaccine for the control and management of Salmonella typhimurium (S. typhimurium). More so, S. typhimurium has been shown to develop resistance against most antibiotics used for treatment of the infection. Capsaicin, a bioactive compound from Capsicum chinense (C. chinenses) is undoubtedly one of the most widely used spice in the world. This heat producing compound is not only been used as food additive but have been demonstrated to possess unique properties that have pharmacological, physiological, and antimicrobial applications. In this work, the antimicrobial property of pure capsaicin or capsaicin extract against $S$. typhimurium is tested to determine the compounds effectiveness in $S$. typhimurium inhibition. Capsaicin extract showed potent inhibition of $S$. typhimurium growth at concentrations as low as $100 \mathrm{ng} / \mathrm{ml}$, whereas pure capsaicin comparatively showed poorer inhibition of the bacteria. Furthermore, both capsaicin extract and pure capsaicin potently blocked S. typhimurium invasion of an animal cell line in vitro. Taken together, this work revealed that capsaicin might work synergistically with dihydrocapsaicin or the other capsaicinoids to inhibit $S$. typhimurium growth, whereas individually, capsaicin or dihydrocapsaicin could potently block the bacteria entry and invasion of Vero cells.
\end{abstract}




\subsection{Introduction}

Over the last 4 to 5 decades, the infections related to nontyphoidal Salmonella have increased and continue to be a significant global burden in health care systems in most countries $(\mathbf{1}, \mathbf{2}, \mathbf{3}, \mathbf{4 , 5})$. These are generally foodborne. Most outbreaks of $S$. typhimurium are facilitated through the acquisition of new traits that enhance their adaptability and virulence $(6,7)$. For instance, the emergence of multidrugresistant (MDR) S. typhimurium DT104 has been demonstrated to be caused by the acquisition of the MDR gene via a plasmid-mediated process (8). Specifically, the MDR-AmpC phenotype $S$. typhimurium and $S$. newport has been demonstrated to be exclusively plasmid mediated by plasmid transfer MDR genes (9).

S. typhimurium is a gram-negative bacterium that causes gastroenteritis, bacteremia, and focal infections. The symptoms include high fever and diarrhea. It is currently treated with trimethoprim and sulfamethoxazole combination or with ciprofloxacin, azithromycin, or ceftriaxone (10). However, the potential to develop resistance against these drugs is high. Most nontyphoidal Salmonella cause mild to severe, including life-threatening, infections (11). In the early 2000, 600 deaths occur per year in the United States alone due to infections with nontyphoidal Salmonella serotypes (12). The resistance of Salmonellae to antimicrobials has been demonstrated to correlate with increased risk of hospitalization, invasive illness, and death $(13,14,15,16,17,18,19)$.

Several published works are highlighting the importance of natural bioactive compounds against microbes $(\mathbf{2 0}, \mathbf{2 1}, \mathbf{2 2})$. Capsaicin, a naturally existing bioactive compound in $C$. chinense have received extensive scientific scrutiny, most works unraveled some of the mechanism of action of this compound and throws new light to its interesting and increasingly huge potential medicinal applications, with the majority of data indicating its potential antimicrobial potency $(\mathbf{2 3}, \mathbf{2 4}, \mathbf{2 5}, \mathbf{2 6}, \mathbf{2 7}, \mathbf{2 8})$. Capsaicin has been demonstrated to possess several pharmacological and physiological properties, for example, capsaicin has been shown to have anti-inflammatory and pain relieving (29), anti-cancer and anti-tumor $(30,31)$ properties, also it has been proved to show positive cardiovascular and gastrointestinal effects $(32,33)$. Dietary capsaicin has been demonstrated to protect cardiometabolic organs from dysfunction (32). Studies underlying the pharmacodynamics of capsaicin revealed that peroxidase is directly linked to capsaicin metabolism, for which peroxidase oxidizes capsaicin (34). Peroxisomes are cellular compartments where the turnover of some reactive anionic species and complex lipids take place. In 
the peroxisomal compartment, capsaicin could be degraded by the peroxisomal $\beta$-oxidation enzymes into acyl-CoAs which inturn serves as as substrate for the mitochondrial carnitine (35).

In a study on the antimicrobial property of capsaicin, Manini et al., 2015, demonstrated that Salmonella enteritis (S. enteritis) did not develop any resistance against capsaicin treatment, and they showed that sublethal concentrations of capsaicin blocked $S$. enteritis from adhering to A549 monolayers cells, and significantly reduced cell-invasiveness (28).

In another study, Omolo et al., 2018 showed that capsaicin from the fruits of $C$. chinense cultivars demonstrated bactericidal and antifungal effects (27). They revealed that L. monocytogenes and $S$. aureus were more susceptible to capsaicin than Salmonella and E. coli O157:H7, and that C. albicans was the most susceptible to capsaicin (27). Qiu et al., 2012 revealed that capsaicin provided protection for mice from methicillin-resistant Staphylococcus aureus infection (36). Chatterjee et al., 2010, also demonstrated that capsaicin is a potent inhibitor of cholera toxin production in Vibrio cholerae (37).

Capsaicin continues to attract major scientific interest specifically relating to its inhibitory potential against food-borne pathogens (38), Helicobacter pylori (39), Pseudomonas aeruginosa, and against MDR-ESBL producing Escherichia coli (40).

The development of antimicrobial resistance is frequent with $S$. typhimurium. For instance, $S$. typhimurium DT104 has been shown to be resistant to cephalosporins, trimethoprim, ampicillin, chloramphenicol, quinolones, streptomycin, sulfonamides, and tetracycline (41). Although the global survey of salmonellosis has been documented (42) relatively little is known about the interaction of this enteric bacterium and one of the bioactive compounds of a commonly consumed food spice called capsaicin. Thus, this work was framed to investigate the effect of capsaicin and capsaicin extract on the growth of S. typhimurium in vitro. Secondly, we investigated the ability of capsaicin or capsaicin extract in blocking the attachment and invasion of animal cells by S. typhimurium.

\subsection{Materials and Methods}

\subsection{Reagents}

All chemicals (Hexane, methanol -LC-MS ( $\geq 99.9 \%)$, water, and ethanol absolute proof ( $\geq 99.5 \%$ ) were all high-performance liquid chromatography (HPLC) grade from Sigma Aldrich, MO, USA. Capsaicin and dihydrocapsaicin standards were purchased from Santa Cruz Biotechnology Inc., CA, USA. Dulbecco modified eagle medium (DMEM) and FBS were obtained from ATCC (Manassa, 
USA). The concentrations of the capsaicin and dihydrocapsaicin standards were evaluated using a stock solution of $6 \mathrm{mg} / \mathrm{ml}$ capsaicin and a stock solution of $5 \mathrm{mg} / \mathrm{ml}$ dihydrocapsaicin. The standards were dissolved completely 10:1 hexane-ethanol mixture and data was published in a previous communication (31).

\subsection{Animal cells and Bacterial Strain}

Bacterial strains BV4012(LeuAam414 supE(gln). T. Poteete) is S. typhimurium strain without phage or extrachromosomal elements. It contains an amber mutation at the amino acid position 414, and this strain was obtained from Dr. Robert Villafane laboratory (Alabama State University, USA). The bacteria strain was grown and maintained in LB broth or LB agar, under $37^{\circ} \mathrm{C}$. Vero cells (ATCC, CCL 81) were obtained from BEI Resources, VA, USA. These cells were cultured and maintain in a T-25 $\mathrm{cm}^{3}$ flask using DMEM supplemented with 10\% FBS and 1\% penicillin-streptomycinamphotericin, at $37^{\circ} \mathrm{C}, 5 \% \mathrm{CO}_{2}$.

\subsection{Description of Plant and Collection of Plant material}

Capsicum chinense fruits were ground to a thick, semi-solid paste which had the characteristic red color as of the fruit. The resulted fine paste was mixed with hexane and eluted. The elute was air-dried to obtain powdered extract (31).

\subsection{Growth kinetics of S. typhimurium post capsaicin, or capsaicin extract administration}

Growth kinetics of $S$. typhimurium were performed in 96 well-plates containing varying concentrations of pure capsaicin, capsaicin extract, or ampicillin. Concentrations used for pure capsaicin, capsaicin extract or ampicillin were $1 \mathrm{mg} / \mathrm{ml}, 100 \mu \mathrm{g} / \mathrm{ml}, 10 \mu \mathrm{g} / \mathrm{ml}, 1 \mu \mathrm{g} / \mathrm{ml}, 100 \mathrm{ng} / \mathrm{ml}$ and $10 \mathrm{ng} / \mathrm{ml}$ for pure capsaicin, capsaicin extract or ampicillin. Growth kinetics were carried out using a similar procedure previously published by Marini et al., 2015 with slight modifications. In summary, $300 \mu$ of $S$. typhimurium $\left(\sim 10 \times 10^{6} \mathrm{CFU} / \mathrm{mL}\right)$ from each treatment were placed on microtiter plates, incubated for $24 \mathrm{~h}$ at $37^{\circ} \mathrm{C}$ and read at OD600 at 1-h intervals using a SpectraMax ${ }^{\circledR}$ ABS Plus Microplate Reader. S. typhimurium grown in LB medium in the absence of capsaicin served as controls. All experiments were performed in triplicate.

\subsection{S. typhimurium live/dead assay}


To test the bactericidal property of capsaicin or capsaicin extract from $C$. chinense, we employed the live/dead assay by using SYBR Green I (Invitrogen, USA) and propidium iodide (Sigma-Aldrich, USA) following a protocol previously published by Magi et al., 2015, that made use of the two nucleic acid dyes that differ in their ability to penetrate bacterial cells. In short, S. typhimurium was grown overnight, and the overnight culture diluted to an OD600 of 0.2 using LB broth supplemented with varying concentrations of capsaicin, capsaicin extract, or ampicillin. An untreated sample served as a control. Treated samples were incubated at $37{ }^{\circ} \mathrm{C}, 5 \% \mathrm{CO}_{2}$ for $60 \mathrm{~min}$. Afterwards, samples were stained with $1 \times$ SYBR Green I or with SYTO-9 and $40 \mu \mathrm{g} / \mathrm{ml}$ propidium iodide, at room temperature for 25 min covered with aluminum foil. Subsequently, cells were harvested on filters $(\varnothing=0.2 \mu \mathrm{m}$, Millipore, USA), and examined under an EVOS FLC microscope (Life Technologies).

\subsection{S. typhimurium membrane integrity test}

To evaluate the mechanism of action of capsaicin or capsaicin extract on $S$. typhimurium, we tested if the compounds acted by disrupting bacterial cell membrane that might lead to cell membrane lysis. To test this hypothesis, $100 \mu \mathrm{l}$ of $S$. typhimurium cells grown to OD of 0.5 were pelleted by centrifugation and resuspended in $1 \mathrm{X}$ PBS, then followed with incubation with lysozyme, capsaicin, capsaicin extract, or ampicillin at concentrations $100 \mu \mathrm{g} / \mathrm{ml}$ or $10 \mu \mathrm{g} / \mathrm{ml}$ for 20 or $60 \mathrm{~min}$. After the set time points of incubations, $50 \mu 1$ of each treatment were mixed with Agarose gel loading dye (Trackit, Thermo Fisher Scientific, USA). Samples were run in $0.8 \%$ agarose gel and gel stained with ethidium monoazide bromide for 30 min. Following rinsing, the agarose gel's bands were captured using ChemiDoc installed with Quantity One software.

\subsection{Vero cell viability determination under capsaicin or capsaicin extract treatment}

To investigate the effect of capsaicin on Vero cells, the cells were cultured in 96-tissue well plates containing DMEM media supplemented with 10\% FBS. Capsaicin at $100 \mu \mathrm{g} / \mathrm{ml}, 10 \mu \mathrm{g} / \mathrm{ml}, 1 \mu \mathrm{g} / \mathrm{ml}$ and $0.1 \mu \mathrm{g} / \mathrm{ml}$ were mixed with the culture media and incubated for 8 hours. Control cultures did not receive capsaicin treatment. At the 8 -h time point, AlamarBlue at $10 \%$ were added to the growing culture and allowed to incubate for an additional $4 \mathrm{~h}$. Absorbance at $570 \mathrm{~nm}$ was read using Cytation 3 imaging/plate reader (BioTek, USA) and data plotted on a bar chart to evaluate the percentage cell viability. 
bioRxiv preprint doi: https://doi.org/10.1101/2022.01.02.474733; this version posted January 2, 2022. The copyright holder for this preprint (which was not certified by peer review) is the author/funder, who has granted bioRxiv a license to display the preprint in perpetuity. It is made available under aCC-BY-ND 4.0 International license.

\subsection{Determination of Vero cell inhibition under capsaicin or capsaicin extract treatment}

To determine the ability of capsaicin or capsaicin extract to inhibit the growth of Vero cells in vitro, the cells were cultured as described above, and following viability assessment using AlamarBlue, the percent cell inhibition was calculated as:

((the absorbance value of the control group) - (absorbance of the treated group))/(sum of both the control and the treated groups) $\times 100$.

\subsection{Anti-adhesion assay}

Vero Cells lines at a density of $1 \times 10^{5}$ were cultured in DMEM media supplemented with 10\% FBS (all from Gibco, USA) in a 96-tissue culture plate (Corning Costar, Milano, Italy) at $37{ }^{\circ} \mathrm{C}$ in an atmosphere containing $5 \% \mathrm{CO}_{2}$ for 24 hours for cells to attach. After $24 \mathrm{~h}$, the media was removed, and $300 \mu \mathrm{l}$ of $S$. typhimurium cells at an OD of 0.3 were added to the growing Vero cells, this was immediately followed with capsaicin, capsaicin extract or media control supplemented DMEM media only. Infection was allowed for 30 min following a similar procedure by Manini et al., 2015 (28). Final concentrations of capsaicin or capsaicin extract in the culture media were $100 \mu \mathrm{g} / \mathrm{ml}$ and $10 \mu \mathrm{g} / \mathrm{ml}$. Prior to infection of the Vero cells, the S. typhimurium was freshly grown to an OD of 0.5 , harvested, and pelleted via centrifugation. Bacteria pellets were washed thrice with $1 \mathrm{X}$ PBS and resuspended in DMEM media to an OD of 0.3 .

To investigate the ability of $S$. typhimurium to attach to the monolayer Vero cells, the wells containing the infected Vero cells, or the controls were washed 3 times with 1X PBS and lysed with chilled distilled water. $300 \mu \mathrm{l}$ of the lysed cells were spread to LB agar plates and incubated overnight at $37^{\circ} \mathrm{C}$. The colony-forming units (CFU) were counted to evaluate the total adherent bacteria in each $300 \mu 1$ of the lysate.

\subsection{Anti-invasion assay}

The anti-invasion capacity of capsaicin or capsaicin extract was evaluated by counting the viable bacteria that survived the antibiotic insults due to their intracellular presence in the host cell's cytoplasm. To investigate the intracellular presence of $S$. typhimurium in infected Vero cells, infected monolayers were washed 3 times with 1X PBS as previously demonstrated by Manini et al., 2015 (28). This was followed with the administration of penicillin $(1 \mathrm{~mL}$ of bactericidal concentrations of 
penicillin $(5 \mu \mathrm{g} / \mathrm{ml}))$ and gentamicin $(100 \mu \mathrm{g} / \mathrm{ml})$, and the samples were allowed to sit for $2 \mathrm{~h}$ at $37^{\circ} \mathrm{C}$ in $5 \% \mathrm{CO}_{2}$. The treated monolayers were washed and lysed with chilled distilled water, then viable intracellular bacteria were assayed by plating $300 \mu \mathrm{l}$ of the lysate on an LB agar plate and cultured overnight. Each assay was repeated thrice.

\subsection{Statistical analyses}

For all statistical data, values were derived from multiple measurements (from replicates of 3 experiments) and averaged. Differences between groups were assessed with paired Student's t-test using OriginPro software. Values are reported as mean \pm SEM. P-values $\leq 0.05$ were considered statistically significant.

\subsection{Results and Discussion}

\subsection{Growth kinetics of S. typhimurium post capsaicin, or capsaicin extract administration}

In this study, administration of pure capsaicin or capsaicin extract isolated from C. chinense fruit demonstrated that both exert bacteria inhibitory activity against S. typhimurium with differing efficacy. Similar reports of capsaicin and dihydrocapsaicin showing antibacterial poperties have been published (28, 43). The capsaicin extract however exerted relatively higher inhibitory activity against $S$. typhimurium than the pure capsaicin at similar concentrations (See Figures 1, 2, and 5). The lowest concentration of capsaicin extract that potently reduced $S$. typhimurium growth was $10 \mathrm{ng} / \mathrm{ml}$ whereas pure capsaicin could not effectively reduced the growth of the bacteria at concentrations of $10 \mu \mathrm{g} / \mathrm{ml}$ or lower (Figure 2). In a control experiment using ampicillin at varying concentrations, a lower concentration of $10 \mathrm{ng} / \mathrm{ml}$ potently reduced the growth of $S$. tyhimurium (Figure 3). As shown in Figure 4, staining of $S$. typhimurium with SYTO-9 and Propidium iodide (PI) indicated that $S$. typhimurium growing on culture media pretreated with $1 \mathrm{mg} / \mathrm{ml}$ of capsaicin extract showed higher $S$. typhimurium killing (indicated by the higher red fluorescence of the PI). The control group that received no treatment showed no red fluorescence (Figure 4) since the undamaged bacterial membrane showed green fluorescence, but those with damaged membranes shows red fluorescence. For immunofluorescent images of other concentrations of capsaicin, capsaicin extract treatment of the bacteria, see Supplementary Figures 1, 2, and 3. 


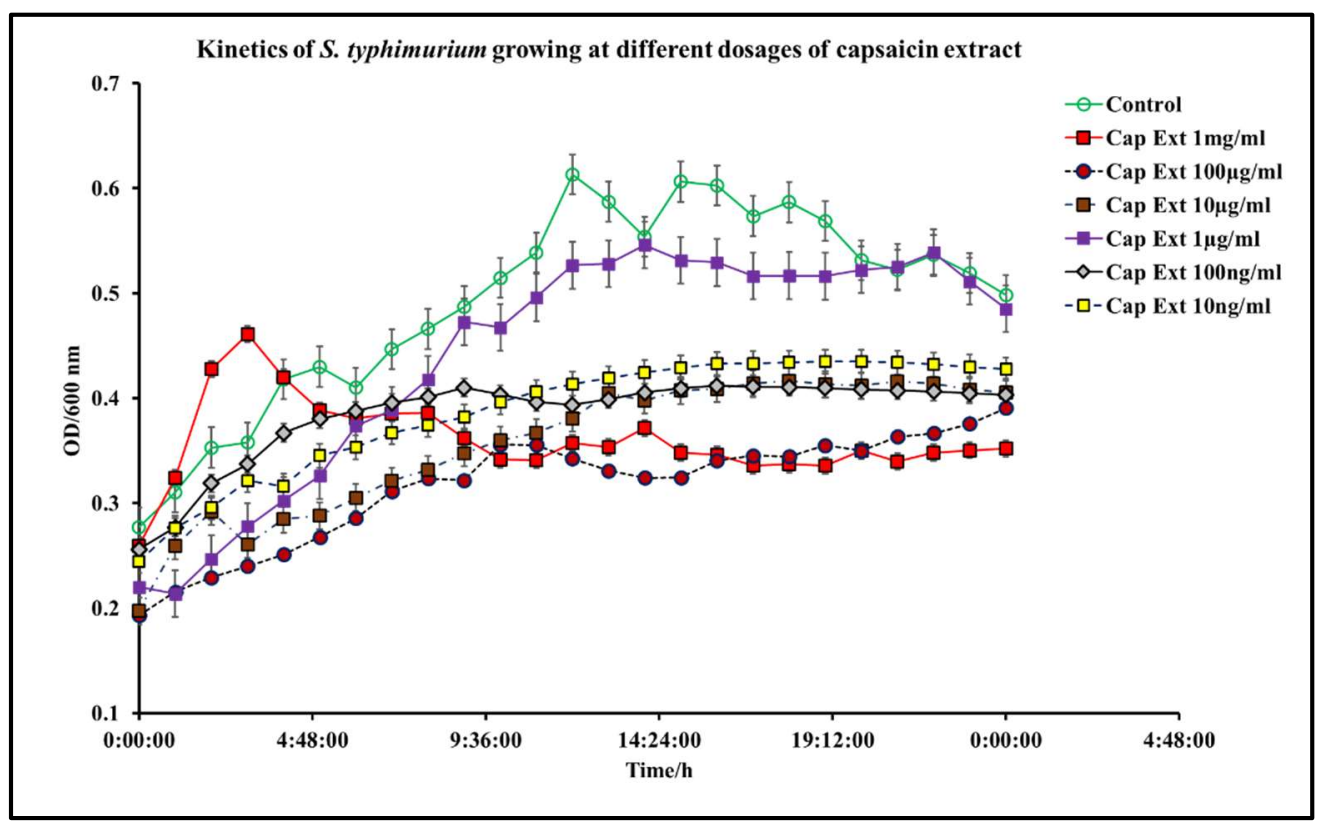

Figure 1. Kinetics of S. typhimurium growth at varying dosages of capsaicin extract. The results represent the average of three independent experiments \pm standard deviation.

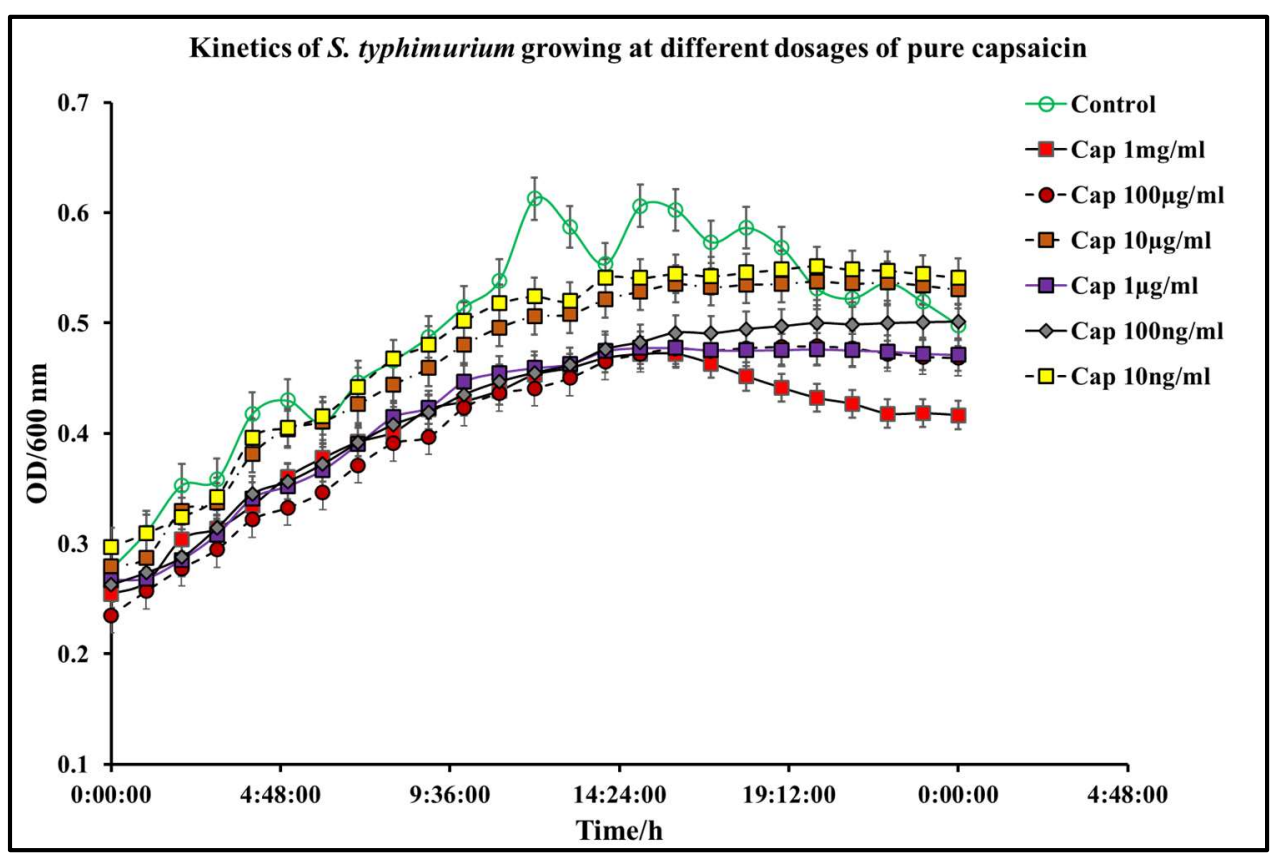

Figure 2. Kinetics of S. typhimurium growth at varying dosages of pure capsaicin. The results represent the average of three independent experiments \pm standard deviation. 


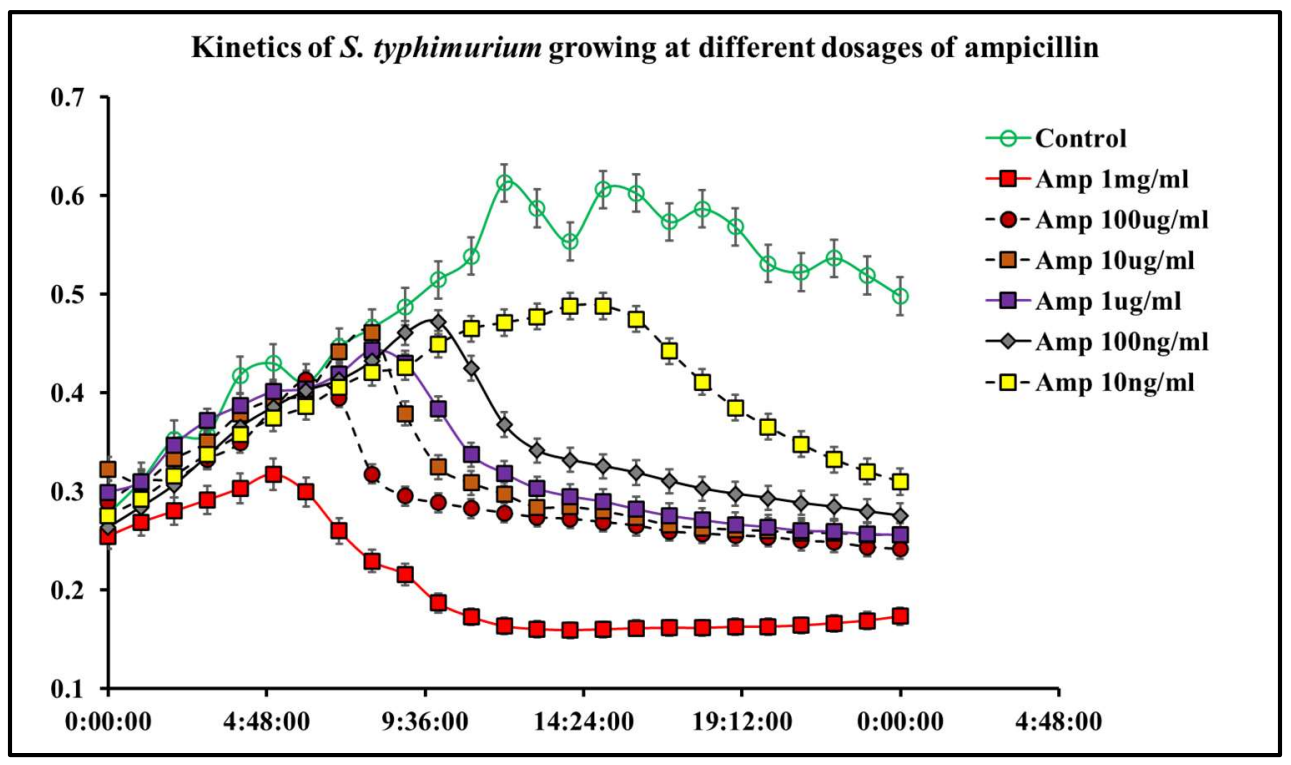

Figure 3. Kinetics of $S$. typhimurium growth at varying dosages of ampicillin. The results represent the average of three independent experiments \pm standard deviation.

\begin{tabular}{|l|l|l|}
\hline & IC50 & $\mathbf{2 4} \mathbf{h}$ \\
\hline Time & $\mathbf{1 2} \mathbf{~ h}$ & $42.22 \mu \mathrm{g} / \mathrm{ml}$ \\
\hline Capsaicin & $34.00 \mu \mathrm{g} / \mathrm{ml}$ & $90.17 \mu \mathrm{g} / \mathrm{ml}$ \\
\hline Capsaicin extract & $23.15 \mu \mathrm{g} / \mathrm{ml}$ & \\
\hline
\end{tabular}

Table 1. Median concentrations of bacterial growth inhibition $\left(\mathrm{IC}_{50 \mathrm{~s}}\right)$ produced by treatment with capsaicin or capsaicin extract. $\mathrm{IC}_{50}$ values are expressed in $\mu \mathrm{g} / \mathrm{ml}$ with a $95 \%$ confidence. $(\mathrm{n}=3$; $\mathrm{p}$ value $\leq 0.05)$.

As shown in Table 1, the $\mathrm{IC}_{50} \mathrm{~s}$ of pure capsaicin and capsaicin extract were calculated for both $12 \mathrm{~h}$ and $24 \mathrm{~h}$ time points. Whereas $12 \mathrm{~h}$ period of pure capsaicin produced an $\mathrm{IC}_{50}$ of $34.0 \mu \mathrm{g} / \mathrm{ml}$, this increased to $42.2 \mu \mathrm{g} / \mathrm{ml}$ at the $24 \mathrm{~h}$ time point. The capsaicin extract showed a lower $\mathrm{IC}_{50}$ of $23.1 \mu \mathrm{g} / \mathrm{ml}$, but this value was increased to $90.2 \mu \mathrm{g} / \mathrm{ml}$ at the $24 \mathrm{~h}$ time point. These increases in $\mathrm{IC}_{50}$ values might be indicative of resistance development of the bacteria against both pure capsaicin and the capsaicin extract. 


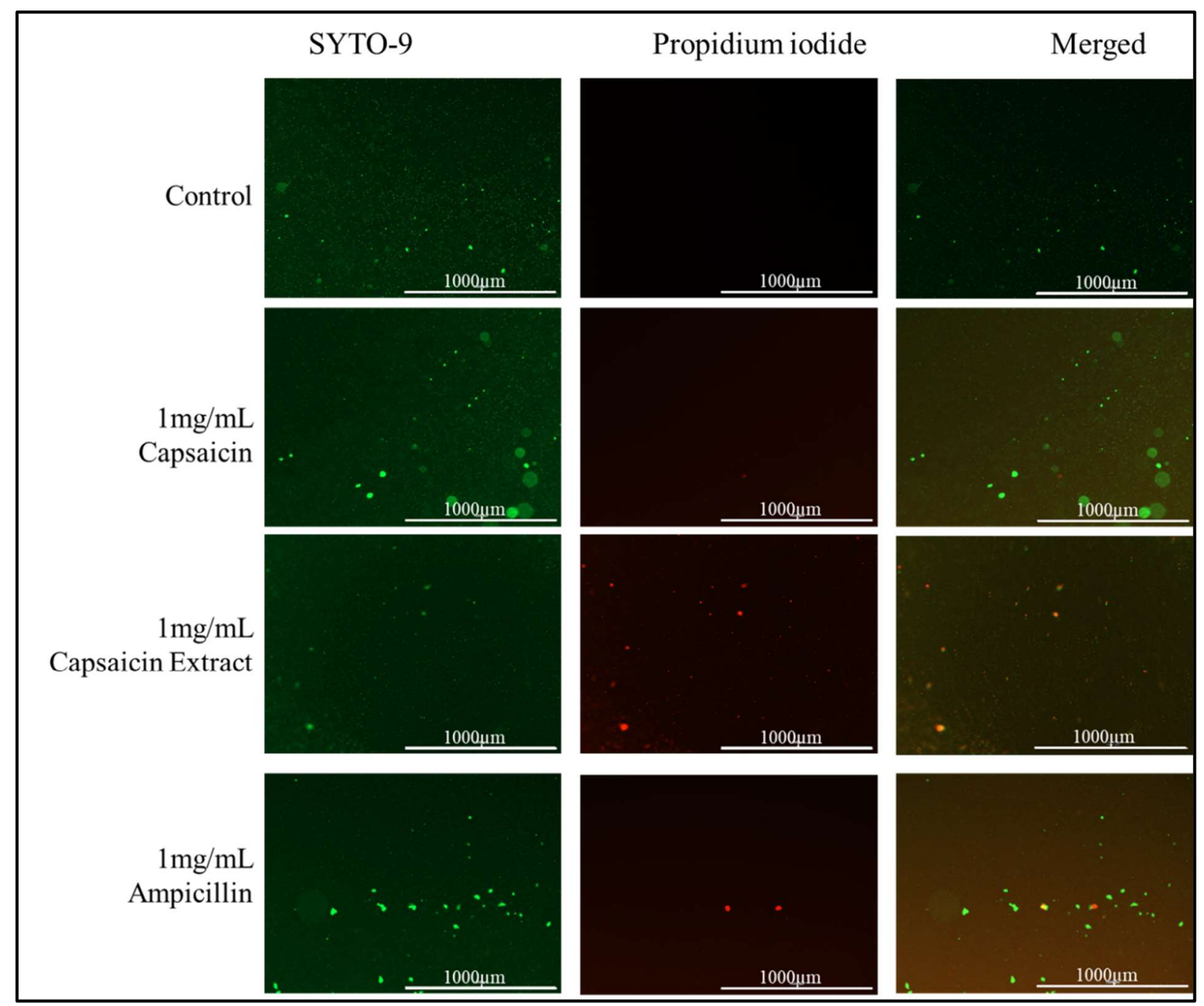

Figure 4. Immunofluorescent images of $S$. typhimurium growing on culture media pretreated with 1 $\mathrm{mg} / \mathrm{ml}$ of pure capsaicin, capsaicin extract or ampicillin (30 min incubation time). Control received no treatment. Undamaged bacterial membrane shows green fluorescence, but those with damaged membranes shows red fluorescence. 


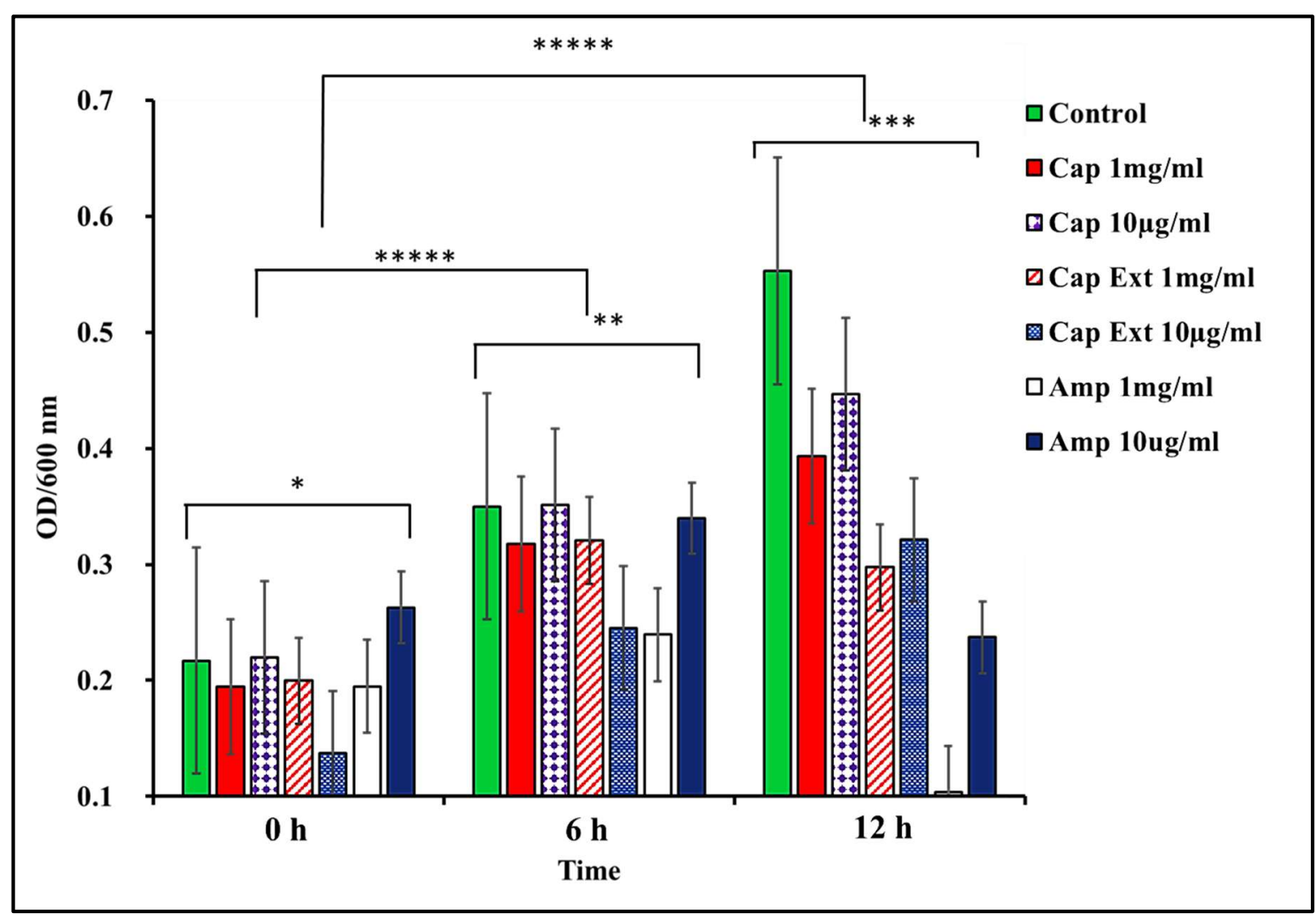

Figure 5. Comparing pure capsaicin, capsaicin extract and ampicillin ability to limit S. typhimurium growth at various culturing time points. ${ }^{*}$ and $* * \mathrm{p}$-value $\leq 0.1, * * *, * * * *$, and $* * * * * \mathrm{p}$-value $\leq 0.05$; $\mathrm{n}=3$.

\subsection{Capsaicin promotes Vero cells growth at lower concentrations and poorly inhibits Vero cell growth at high concentrations}

In this work, Vero cells were cultured in DMEM medium supplemented with varying concentrations of pure capsaicin or capsaicin extract. Viabilities of these cells were shown not to be significantly different $(\mathrm{p} \leq 0.05)$. However, there were observed slightly higher growth of Vero cells at $0.1 \mu \mathrm{g} / \mathrm{ml}$ of capsaicin than all other treatment groups (Figure 6). Morphologically, no distinct differences were observed between cells of the different treatments groups of capsaicin, or capsaicin extract (Figure 8). Infecting Vero cells with $S$. typhimurium showed that the bacteria attached to host Vero cells within 30 min post infection (Figure 9). 


\subsection{Determination of Vero Cell inhibition under capsaicin or capsaicin extract treatment}

To determine if pure capsaicin or capsaicin extract exerted any growth inhibition on Vero cells, these cells were grown in DMEM media (containing 10\% FBS) supplemented with varying concentrations of capsaicin or capsaicin extract. Growth inhibition was evaluated using AlamarBlue assay (44). While inhibition was recorded for pure capsaicin at concentration of $100 \mu \mathrm{g} / \mathrm{ml}, 10 \mu \mathrm{g} / \mathrm{ml}$ and $1 \mu \mathrm{g} / \mathrm{ml}, 0.1$ $\mu \mathrm{g} / \mathrm{ml}$ of the pure compound seemed to promote Vero cell growth (Figures 6 and 7). On the other hand, $1 \mu \mathrm{g} / \mathrm{ml}$ and $0.1 \mu \mathrm{g} / \mathrm{ml}$ of capsaicin extract promoted Vero cells growth whereas $100 \mu \mathrm{g} / \mathrm{ml}, 10$ $\mu \mathrm{g} / \mathrm{ml}$ showed cell inhibition (Figure 7).

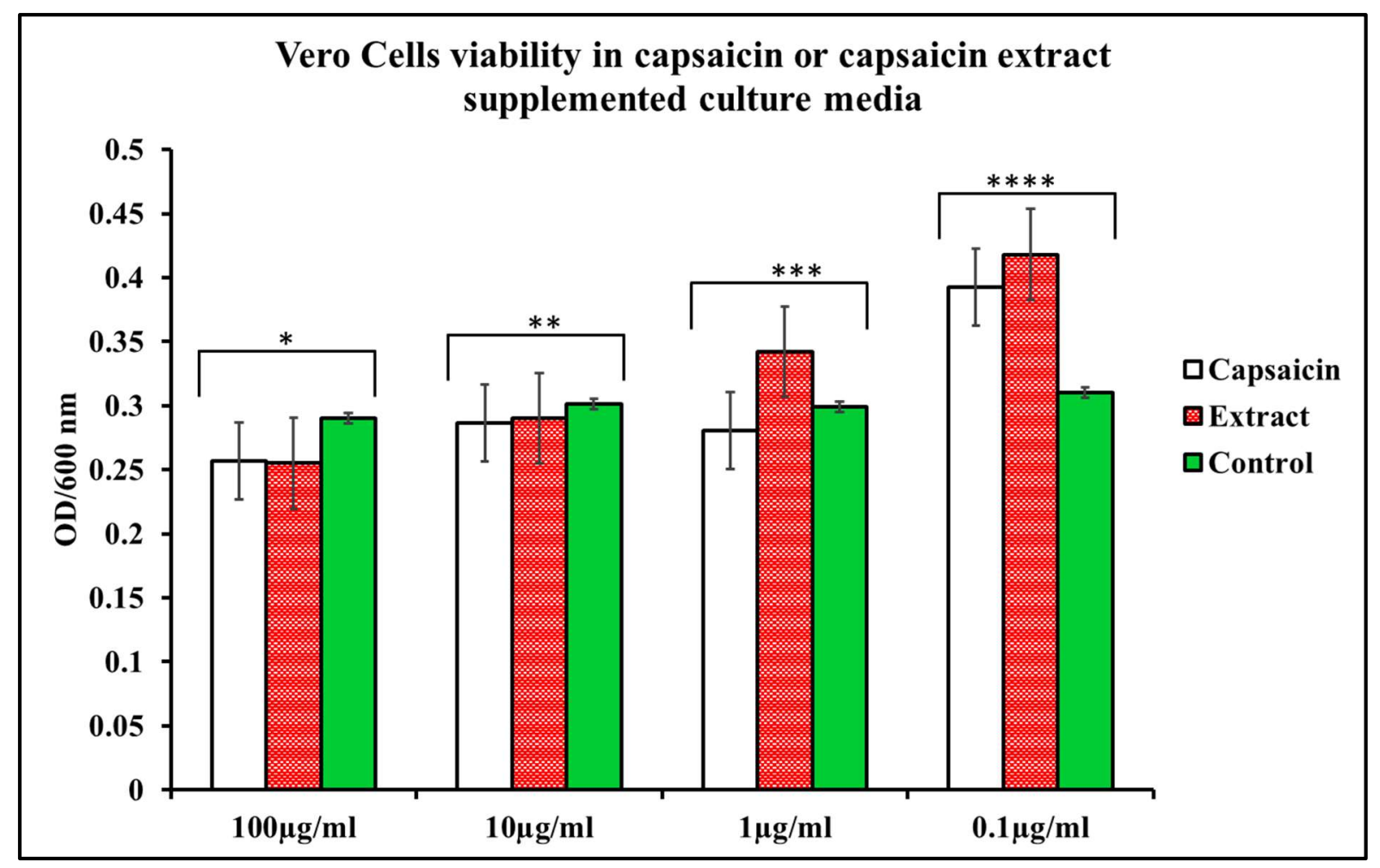

Figure 6. Viabilities of Vero cells in pure capsaicin or capsaicin extract at varying doses. *,**,*** and $* * * * \mathrm{p}$-value $\leq 0.1 ; \mathrm{n}=3$. 


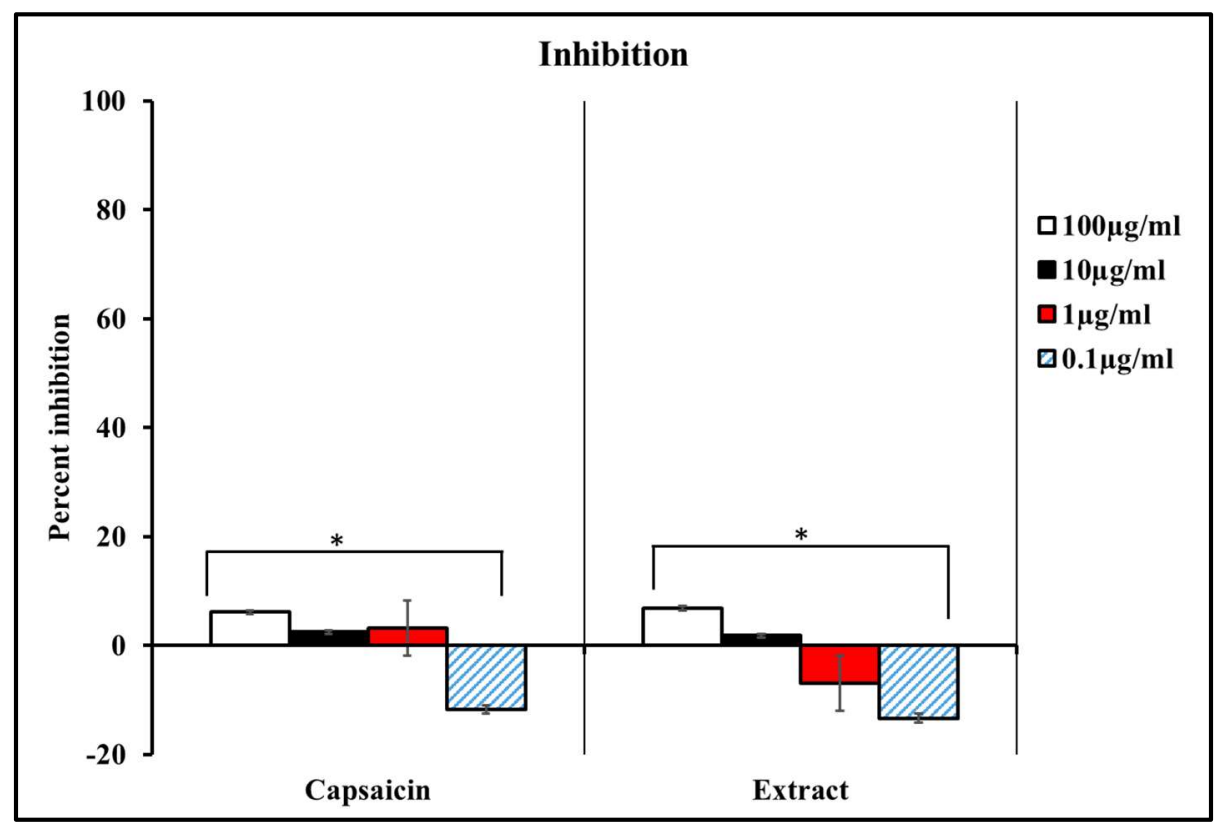

Figure 7. Percentage growth inhibition of Vero cells in pure capsaicin or capsaicin extract at varying doses. * p-value $\leq 0.05, \mathrm{n}=3$.

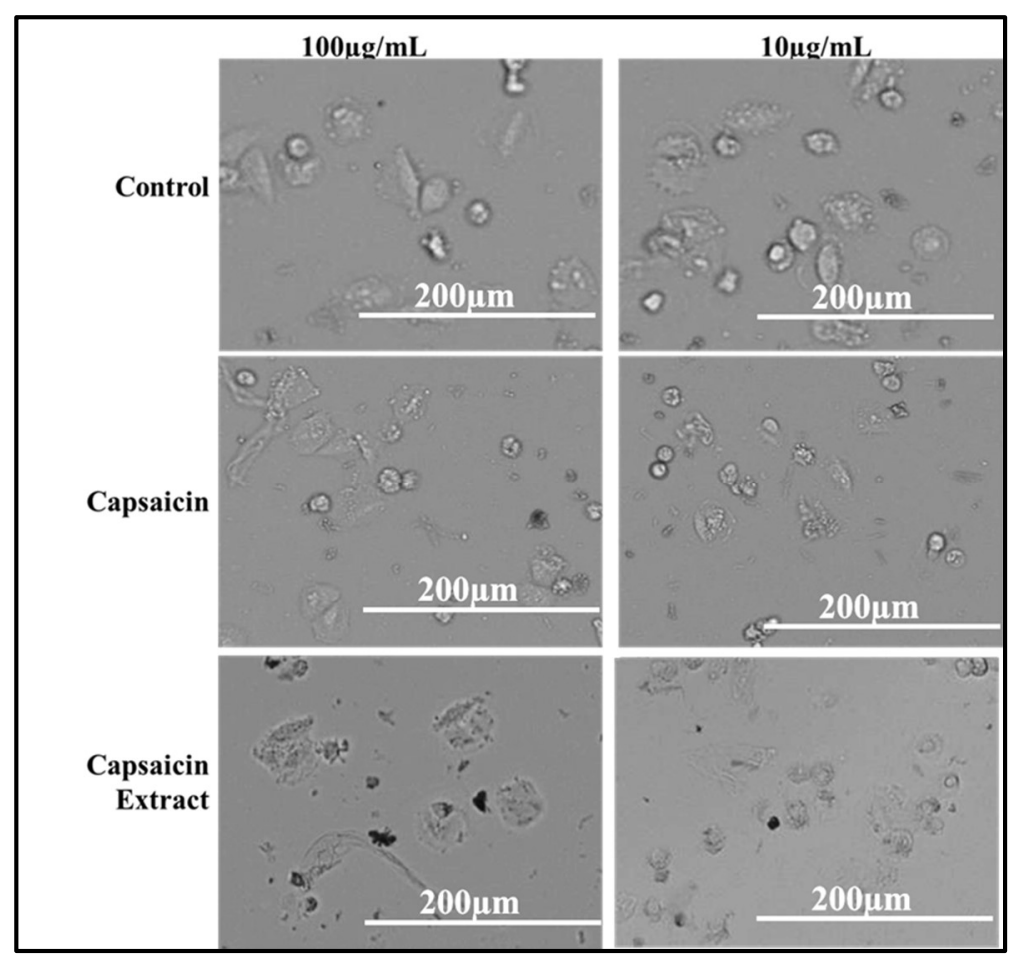

Figure 8. Phase Contrast microscopic images depicting Vero cells growing in media supplemented with capsaicin or capsaicin extract for 8 hours. Control group received no treatment. 
bioRxiv preprint doi: https://doi.org/10.1101/2022.01.02.474733; this version posted January 2, 2022. The copyright holder for this preprint (which was not certified by peer review) is the author/funder, who has granted bioRxiv a license to display the preprint in perpetuity. It is made available under aCC-BY-ND 4.0 International license.

\subsection{Adherence of S. typhimurium to Vero cells}

The intracellular presence of $S$. typhimurium can constitute a major reservoir of continuing bacteria in vivo that subsequently cause reinfections. The survival of $S$. typhimurium inside the host cell requires first the bacteria's ability to attach to the host, penetrate into the host cell, and invade it. Thus the invasion and survival of S. typhimurium in the Vero cells presents a huge challenge to drugs that do not act intracellularly, e.g. penicillin

Using the anti-adherence assay, we demonstrated both pictorially and quantitatively the adhesion of $S$. typhimurium to Vero cells after 30 min post-infection. Vero cells were inoculated with S. typhimurium for $30 \mathrm{~min}$ as described in the anti-adhesion assay in materials and methods. The capsaicin extracttreated group showed very low bacteria adhesion (Figures 9 and 10) as compared to the control and the pure capsaicin-treated samples. Quantitatively, at p-values below 0.05, there was no significant difference between the CFUs counted between the different groups, indicating that adherence to cells was not significantly affected by treatment to pure capsaicin or capsaicin extract (Figure 12A). The remarkably high number of bacteria adhering to Vero cells at pure capsaicin concentration of $100 \mu \mathrm{g} / \mathrm{ml}$ was contrasted sharply with the drastic decrease in the number of intracellular bacteria that were recorded in the presence of same concentration of pure capsaicin concentrations (see Figures $\mathbf{1 0}$ and 12B). There was slighly lower number of bacteria adhering to Vero cells when treated with $100 \mu \mathrm{g} / \mathrm{ml}$ of capsaicin extract (Figure 10).

\subsection{Invasion of S. typhimurium into Vero cells}

The internalization of $S$. typhimurium into the host cells is indicative of invasion. To investigate the capacity of pure capsaicin or capsaicin extract in blocking the entery of S. typhimurium into Vero cells were carried out (Figures 11 and 12B). It was evident that at $100 \mu \mathrm{g} / \mathrm{ml}$ both pure capsaicin and capsaicin extract potently blocked the invasion of S. typhimurium into Vero cells since very few CFUs could be observed (Figure 11) or recorded (Figure 12B). 

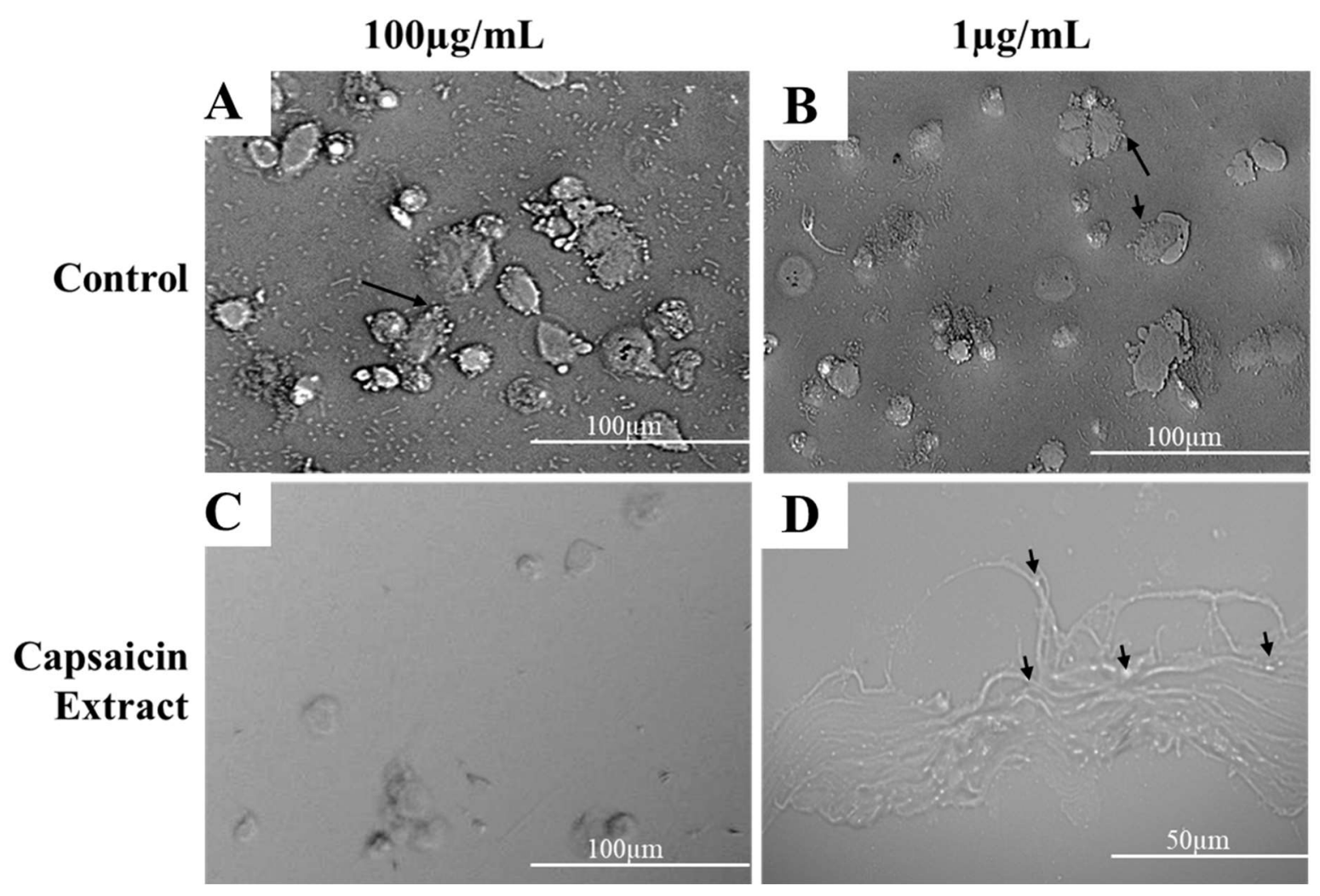

Figure 9. Phase Contrast microscopy depicting Vero cells infected with S. typhimurium. Treated samples received capsaicin extract at $100 \mu \mathrm{g} / \mathrm{ml}$ or $1 \mu \mathrm{g} / \mathrm{ml}$ respectively, whereas the control received 1X PBS, infection was allowed for 8 hours. Black arrows in (A) and (B) shows attached S. typhimurium to Vero cells, black arrows in (C) shows internalized S. typhimurium in Vero cells. 


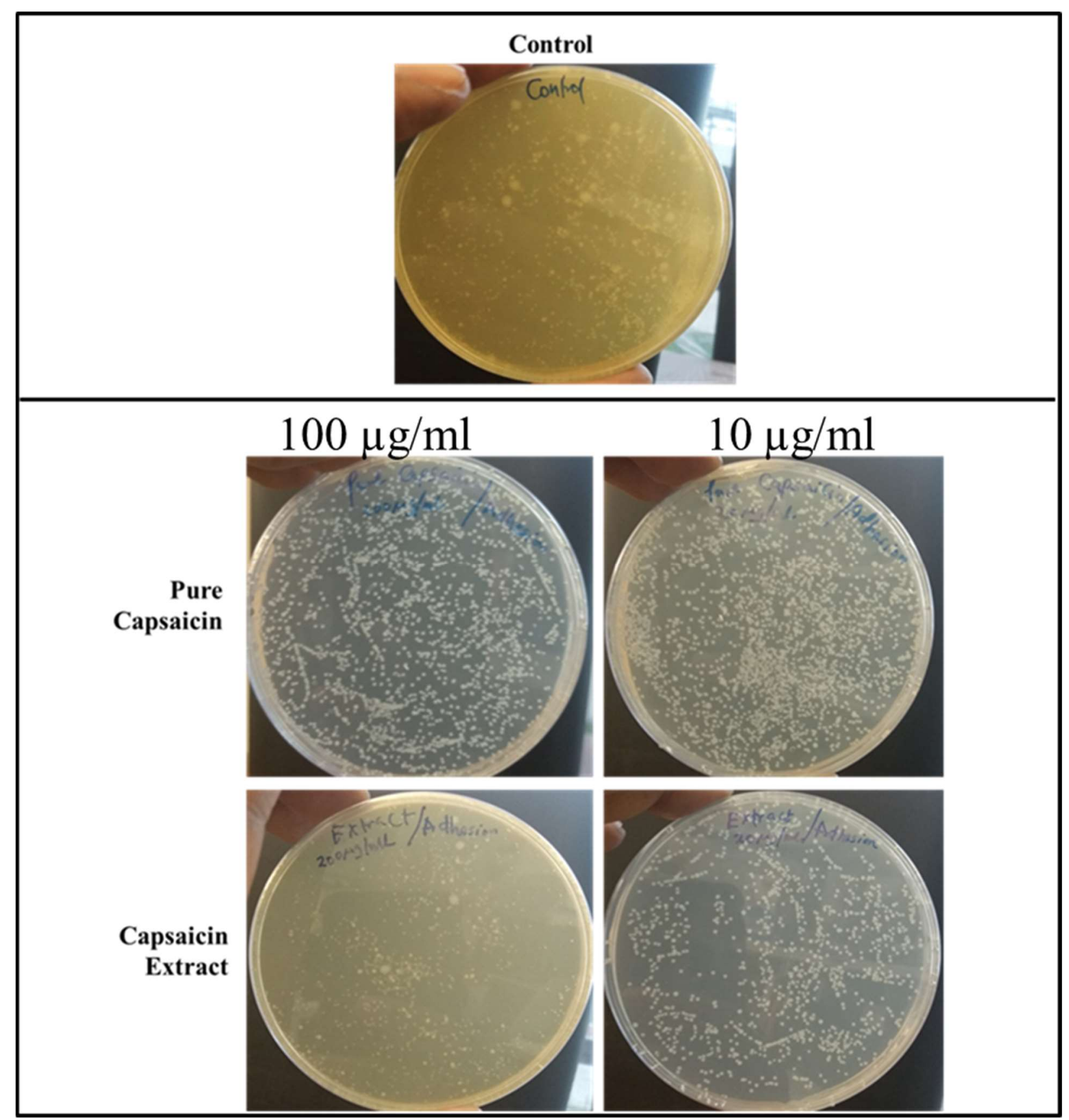

Figure 10. Images of Agar plates depicting the CFUs of S. typhimurium in bacteria adhesion assay. Monolayer Vero cells growing in media supplemented with capsaicin at varying concentrations were infected with S. typhimurium and incubated for 30 minutes, washed thrice with 1X PBS to remove bacterial cells in suspension. Vero cells were then lysed with chilled distill water and plated on Agar plates overnight. The treated samples received capsaicin extract at $100 \mu \mathrm{g} / \mathrm{ml}$ or $10 \mu \mathrm{g} / \mathrm{ml}$ respectively, whereas the control received $1 \mathrm{X}$ PBS. 


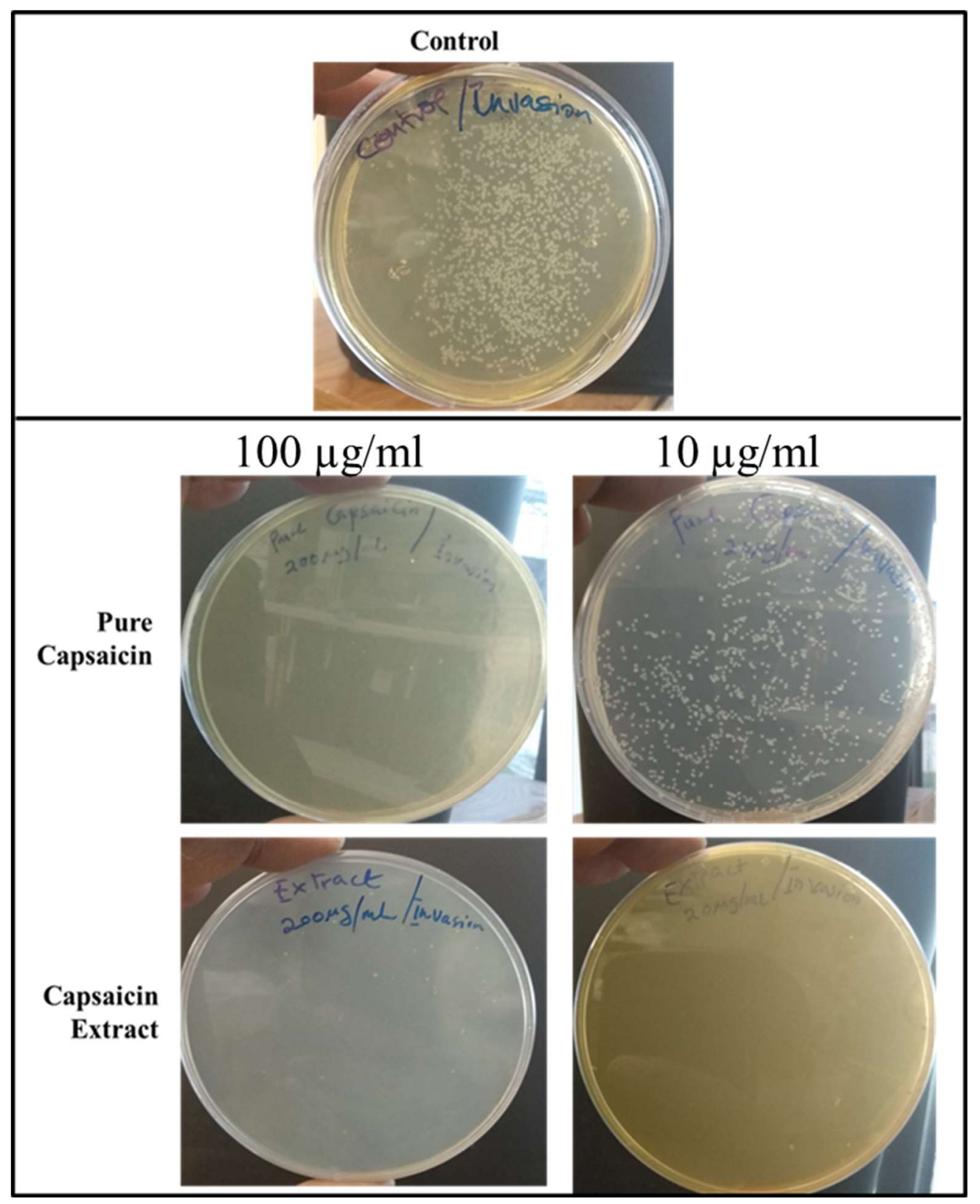

Figure 11. Images of Agar plates depicting the CFUs of S. typhimurium in bacteria invasion assay. Monolayer Vero cells growing in media supplemented with capsaicin at varying concentrations were infected with S. typhimurium and incubated for 2 hours to allow for bacterial cell invasion of Vero cells. Then the infected monolayer Vero cells were washed thrice with 1X PBS to remove bacterial cells in suspension and followed with antibiotic treatment for $2 \mathrm{~h}$ at $37{ }^{\circ} \mathrm{C}$ in $5 \% \mathrm{CO}_{2}$ to kill bacterial cells that adhered to Vero cells but did not internalize. Then antibiotics were washed off and Vero cells lysed with chilled distill water and plated on Agar plates overnight. The treated samples received capsaicin extract at $100 \mu \mathrm{g} / \mathrm{ml}$ or $10 \mu \mathrm{g} / \mathrm{ml}$ respectively, whereas the control received $1 \mathrm{X}$ PBS. 


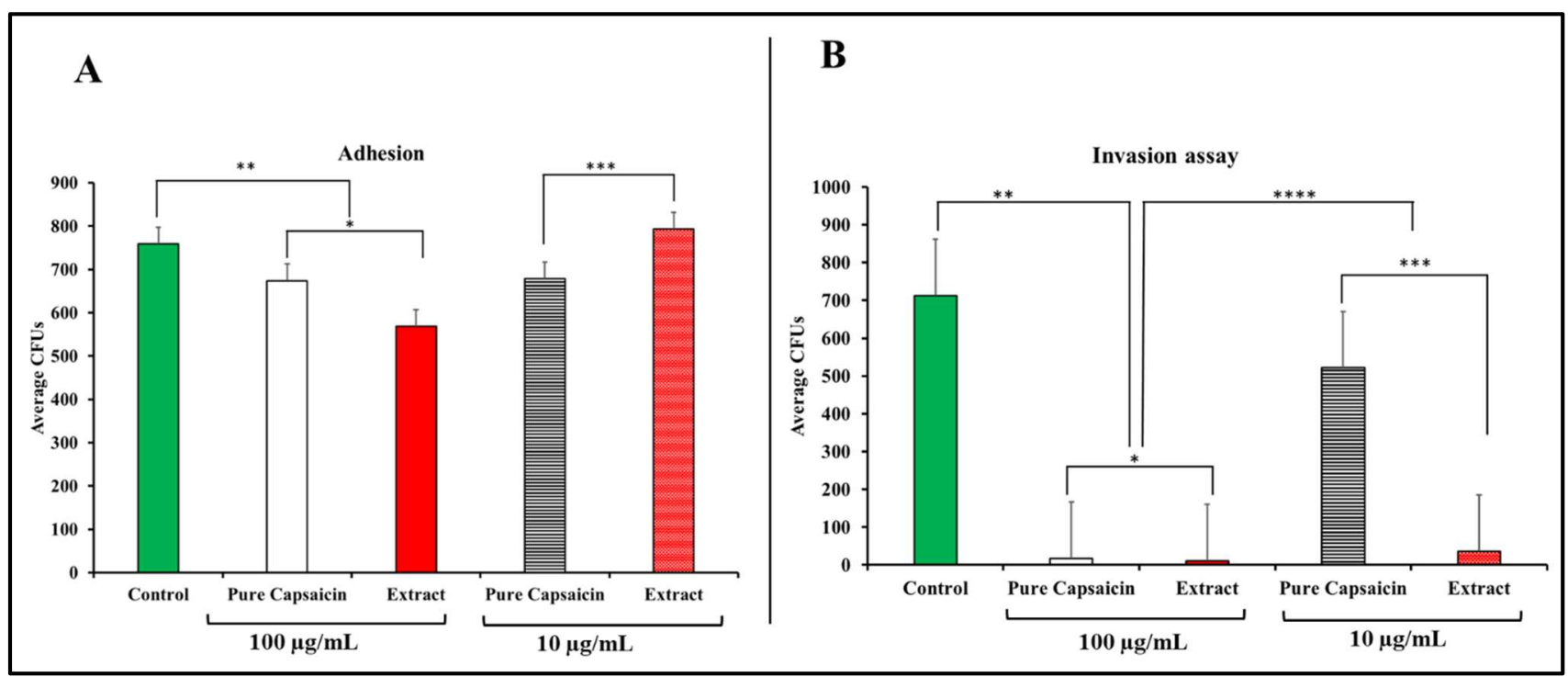

Figure 12. Bar charts depicting the quantitative enumeration of CFUs of $S$. typhimurium in bacteria anti-adhesion and anti-invasion assays. For the anti-adhesion assay, no antibiotics were applied. For the anti-invasion, antibiotics were applied, then the antibiotics were washed off and Vero cells lysed with chilled distill water and plated on Agar plates overnight. The treated samples received capsaicin extract at $100 \mu \mathrm{g} / \mathrm{ml}$ or $10 \mu \mathrm{g} / \mathrm{ml}$ respectively, whereas the control received 1X PBS. For Figure 12A; * and $* *$ p-value $\leq 0.1, * * * \mathrm{p}$-value $\leq 0.05 ; \mathrm{n}=3$. For Figure 12B; $* \mathrm{p}$-value $\leq 0.361, * *, * * *$ and $* * * * \mathrm{p}-$ value $\leq 0.005 ; \mathrm{n}=3$. 


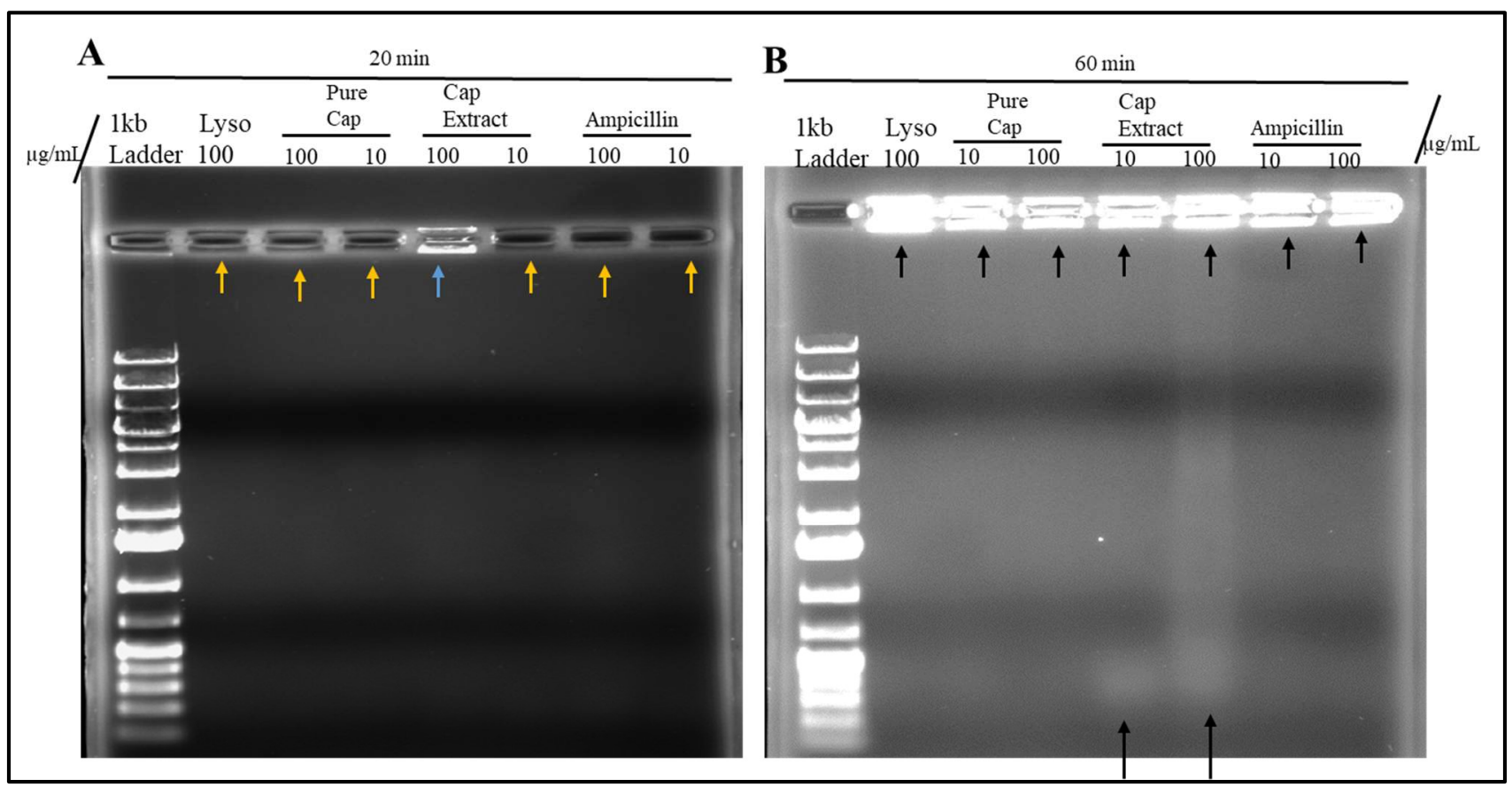

Figure 13. S. typhimurium membrane integrity assessment via agarose gel electrophoresis. (A) Bacterial cells were incubated in the said concentration for $20 \mathrm{~min}$. (B) Bacterial cells were incubated in the said concentration for $60 \mathrm{~min}$. Gels were run at 100 volts for $60 \mathrm{~min}$. Trail of blurry band can be observed in (B) as shown by the black arrows at capsaicin extract (Cap extract) lane $100 \mu \mathrm{g} / \mathrm{ml}$. A fainter band can be observed at the $10 \mu \mathrm{g} / \mathrm{ml}$ lane of capsaicin extract. In (A) no blurry band trail can be seen. Pure cap = pure capsaicin.

\subsection{S. typhimurium membrane integrity assessment}

To evaluate the mechanism of action of capsaicin or capsaicin extract on S. typhimurium, we tested if the compounds acted by disrupting bacterial cell membrane structure that might lead to cell membrane lysis. Lysed bacterial cells will have their genetic content extracellularly and will be subjected to migrate through the matrix of the gel. However intact cell membranes will keep DNA enclosed within cells and block their movement through the matrix of the gel. To test this hypothesis, S. typhimurium cells grown to OD of 0.5 were pelleted by centrifugation and re-suspended in $1 \mathrm{X}$ PBS. Aliquots of the resuspended bacteria were incubated with lysozyme, capsaicin, capsaicin extract, or ampicillin at concentrations $100 \mu \mathrm{g} / \mathrm{ml}$ or $10 \mu \mathrm{g} / \mathrm{ml}$ for 20 or $60 \mathrm{~min}$. Afterward, $50 \mu \mathrm{l}$ of each treatment was mixed with Agarose gel loading dye (Trackit, Thermo Fisher Scientific, USA). Samples were run in 0.8\% agarose gel, then the gel stained with ethidium monoazide bromide for $30 \mathrm{~min}$. 
As depicted in Figure 13, S. typhimurium membrane integrity assessment via agarose gel electrophoresis was carried out to ascertain the effect of pure capsaicin or capsaicin extract on the $S$. typhimurium membrane integrity. As shown in Figure 13A, the bacterial cells incubated for a brief period (20 min) showed no band intensities nor band migrations except for lane capsaicin extract lane $100 \mu \mathrm{g} / \mathrm{ml}$. In Figure 13B, bacterial cells were incubated longer time point (60 min) which also showed some significantly higher band intensities in all wells. Trail of a blurry band can be observed in Figure 13B, as shown by the black arrows at capsaicin extract lane $100 \mu \mathrm{g} / \mathrm{ml}$. A fainter band can be observed at the $10 \mu \mathrm{g} / \mathrm{ml}$ lane too of capsaicin extract. As can be observed in Figure 13A, no blurry band trail could be seen. However, we observe a band at the well for $100 \mu \mathrm{g} / \mathrm{ml}$ capsaicin extract, with no bands observed in all other wells. This might indicate that at 20 min treatment, most bacterial cell membranes at all treatment groups except the $100 \mu \mathrm{g} / \mathrm{ml}$ capsaicin extract treatment group still maintained their cell membrane integrity. However, with continued incubation $(60 \mathrm{~min})$, most of these agents created slight changes to the membrane structures of the bacteria, allowing for the membrane-impermeable dye to enter the bacteria and intercalate with the bacterial DNA hence giving off significantly high band intensities.

\subsection{Discussion and conclusion}

Apart from capsaicin and dihydrocapsaicin, other major capsaicinoids of $C$. chinense include nordihydrocapsaicin, homodihydrocapsaicin and homocapsaicin. Majority of capsaicinoids (90\%) are mainly capsaicin and dihydrocapsaicin. Capsaicin is colorless, odorless hydrophobic, lipophilic, and crystalline alkaloid, with a molecular weight of $305.40 \mathrm{~g} / \mathrm{mol}$. It is oil, alcohol, and fat soluble. Several research has shown an increasingly huge potential medicinal applications of capsaicin, with majority of data indicating its potential antimicrobial potency. In this work, S. typhimurium, one of the major bacteria that causes several health outbreaks in the world that are related to contaminated foods and water is tested against pure capsaicin and capsaicin extract.

S. typhimurium is a Gram-negative bacteria composed of two membranous structures; the inner one known as the plasma membrane which is made of a phospholipids bilayer, and the outer membrane 
which consists of proteins, including porins, receptors, and an asymmetric distribution of lipids (45).

The effect of pure capsaicin or capsaicin extract from $C$. chinense on this bacteria has been shown via several assays. We proved that pure capsaicin and capsaicin extract showed potent antibacterial activity against this bacteria, however, the capsaicin extract performed better at inhibiting the bacterial growth than the pure sample. At higher concentrations of the capsaicin extract, reduction in bacterial cell growth were comparable to the well known antibiotic ampicillin (Figures 1, 3, and 5).

The antibacterial property of the capsaicin extract or the pure capsaicin against S. typhimurium was also assessed via live/dead assay using SYBR green I or SYTO-9 and propidium idodide, in which bacteria with intact cell membranes gives off green fluorescences whereas, cells with damaged membranes show red fluorescence. Our assay showed that capsaicin extract exhibited higher bactericidal activity against $S$. typhimurium than the pure sample. This we presumed might be due to membrane disruption as proposed by the higher red fluorescence. This inference has also be proposed by early researchers $(28,46,47,48)$.

Both pure capsaicin and capsaicin extract at lower concentrations showed minimal to no effect on Vero cell growth inhibition, interestingly, below $1 \mu \mathrm{g} / \mathrm{ml}$, both the pure capsaician and capsaicin extracted seemed to promote Vero cell growth (Figures 6 and 7).

To examine the mechanism of action of the pure capsaicin or capsaicin extract on S. typhimurium killing, we postulated bacterial membrane damage. To test for this hypothesis, we employed ethidium monoazide bromide which is a fluorescent dye that binds covalently to nucleic acids however it is cell membrane impermeable. To therefore bind to cell's nucleic acid then such bacteria must have compromised membranes (49). Our assay revealed that few minutes of treatment of capsaicin extract to S. typhimurium was sufficient to significantly damage the bacterial cell membrane hence allowing the entry of the dye into whole cells loaded into the lane (Figure 13A, lane $100 \mu \mathrm{g} / \mathrm{ml}$ of capsaicin 
extract). In Figure 13B however, when the bacterial cells were incubated for longer time point, significantly higher band intensities in all wells were recorded, nonetheless no DNA migration through the matrix of the gel were recorded except the capsaicin extract treatment groups. The leaking of genome out of the cells might be indicative of cell lysis, and not minor cell membrane structural damages, thus allow the cytoplasmic content to flow extracellularly. As indicated in Figure 13B, only capsaicin extract treatment cause this leaking phenomenon at 1-hour post treatment. This seems to indicate that even though capsaicin does exert membrane damage, the pure capsaicin does not cause cell lysis, however, the capsaicin extract at longer incubation caused cell lysis.

This is an interesting and compelling property of capsaicin's mechanism of action as an antimicrobial. Further studies are required at this stage to show the biochemical mechanism of action of capsaicin extract's antibacterial activity against $S$. typhimurium. However, studies on the effect of capsaicin on biomimetic membranes gives a perfect starting point for consideration. Using a laurdan fluorescent molecular probe, Sharma et al., 2019 demonstrated the effect of capsaicin on membrane fluidity, which is a very crucial biophysical property of membranes (46). They demonstrated that liposomes with higher capsaicin concentrations $(10 \%$ and $20 \%)$ showed higher fluidity than lower capsaicin concentrations (Capsaicin 5\%). Additionally, this group demonstrated that the capsaicin caused thermoinduced membrane excess area, hence promoting liposomes to fluctuate more upon increasing temperature (46).

Since capsaicin and its derivatives are mostly lipophilic in nature, their interaction on cell membranes present an important pharmacological and physiological phenomena. Eventhough, it is a published fact that this molecule selectively binds to the transient receptor vanilloid 1 (TRPV1) (50) this specific mechanism might not be the case in this study since were are dealing with prokaryotic organisms. This molecule is amphiphilic with hydrophilic 4-hydroxy-3-methoxybenzyl-8-methylnon-6-enamide group 
and a hydrophobic 7-methyl-8-octene moiety (46). For this reason, capsaicin has the capacity to insert itself into the plasma membrane phospholipid bilayer that could substantially certain biophysicochemical conditions cause "membrane structural discordance" or damage leading to cell membrane permeability (51). The lytic observation in the capsaicin extract treatment might be due to synergistic effect of capsaicin and dihydrocapsaicin found in the extract instead of the pure capsaicin sample.

The $\mathrm{IC}_{50}$ values of pure capsaicin and the capsaicin extract were calculated for both $12 \mathrm{~h}$ and $24 \mathrm{~h}$ time points. Whereas $12 \mathrm{~h}$ period of capsaicin produced an $\mathrm{IC}_{50}$ of $34.0 \mu \mathrm{g} / \mathrm{ml}$, this increased to $42.2 \mu \mathrm{g} / \mathrm{ml}$ at the $24 \mathrm{~h}$ time point. The capsaicin extract showed a lower $\mathrm{IC}_{50}$ of $23.1 \mu \mathrm{g} / \mathrm{ml}$, but this value was increased to $90.2 \mu \mathrm{g} / \mathrm{ml}$ at the $24 \mathrm{~h}$ time point. These increase in $\mathrm{IC}_{50}$ values might be indicative of resistance development of the bacteria against both pure capsaicin and the capsaicin extract. Marini et al., 2015 reported minimum inhibitory concentrations of capsaicin that produced complete bactericidal activity on Salmonella enteritis to be between $64-128 \mu \mathrm{g} / \mathrm{ml}$. Also, studies by Orlo et al., 2021(52) showed that capsaicin at $\mathrm{IC}_{50}$ s of $4.79,1.21,4.28$ and $0.68 \mathrm{mM}$ were effective against E. coli, $P$. aeruginosa, S. putrefaciencs and $S$. aureus respectively, thus corroborating our findings that capsaicin or capsaicin extract has antibacterial activity.

The observed capsaicin effect on S. typhimurium killling might also be due in part to other factors such as reactive oxygen production, membranes leaks that disrupts bacterial energy biosynthesis, and intracellular influx of ions that can potentially disrupt cellular processes. Capsaicin has also be known to be involved in lipid oxidation (33), the oxidation of the bacterial membrane might have downstream biological ramifications that might cause the bacterial cell death.

At the present stage, further work is needed to fully elucidate the mechanism of capsaicin or capsaicin extract blockage of S. typhimurium invasion, as well as definitively prove the involvement of capsaicin 
in the plasma membrane disruption of these Gram-negative bacteria. Currently, ongoing work is being carried out in our laboratory to understand the relationship between S. typhimurium biofilm formation reduction in the presence of capsaicin as well as the molecular mechanisms orchestrating such observation. To investigate the biotransformation of capsaicin in S. typhimurium will also be an exciting undertaking.

\section{Acknowledgements}

We are grateful to Alabama State University and the College of Science, Mathematics and Technology for their continuous support. We acknowledge Dr. Derrick Dean for laboratory space and OriginPro Software. Also, we acknowledge the BEI Resources, NIAID, NIH for providing the African Green Monkey Vero cell lines for the studies.

Conflict of interest: The authors wish to state that there is no conflict of interest.

\section{References}

1 Voetsch, A.C., Van Gilder, T.J., Angulo, F.J., Farley, M.M., Shallow, S., Marcus, R., Cieslak, P.R., Deneen, V.C., Tauxe, R.V. and Emerging Infections Program FoodNet Working Group, 2004. FoodNet estimate of the burden of illness caused by nontyphoidal Salmonella infections in the United States. Clinical infectious diseases, 38(Supplement_3), pp. S127-S134.

2 Chalker, R.B. and Blaser, M.J., 1988. A review of human salmonellosis: III. Magnitude of Salmonella infection in the United States. Reviews of infectious diseases, 10(1), pp.111-124.

3 Tauxe, R.V., 1999. Salmonella Enteritidis and Salmonella Typhimurium DT104: successful subtypes in the modern world. Emerging infections 3, pp.37-52.

4 Gomez, T.M., Motarjemi, Y., Miyagawa, S., Käferstein, F.K. and Stöhr, K., 1997. Foodborne salmonellosis. World health statistics quarterly. Rapport trimestriel de statistiques sanitaires mondiales, 50(1-2), pp.81-89.

5 Olsen, S.J., DeBess, E.E., McGivern, T.E., Marano, N., Eby, T., Mauvais, S., Balan, V.K., Zirnstein, G., Cieslak, P.R. and Angulo, F.J., 2001. A nosocomial outbreak of fluoroquinoloneresistant Salmonella infection. New England Journal of Medicine, 344(21), pp.1572-1579.

6 Foley, S.L., Johnson, T.J., Ricke, S.C., Nayak, R. and Danzeisen, J., 2013. Salmonella pathogenicity and host adaptation in chicken-associated serovars. Microbiology and Molecular Biology Reviews, 77(4), pp.582-607.

7 Maurelli, A.T., 2007. Black holes, antivirulence genes, and gene inactivation in the evolution of bacterial pathogens. FEMS microbiology letters, 267(1), pp.1-8.

8 Butaye, P., Michael, G.B., Schwarz, S., Barrett, T.J., Brisabois, A. and White, D.G., 2006. The clonal spread of multidrug-resistant non-typhi Salmonella serotypes. Microbes and Infection, 8(7), pp.1891-1897. 
9 Giles, W.P., Benson, A.K., Olson, M.E., Hutkins, R.W., Whichard, J.M., Winokur, P.L. and Fey, P.D., 2004. DNA sequence analysis of regions surrounding bla CMY-2 from multiple Salmonella plasmid backbones. Antimicrobial Agents and Chemotherapy, 48(8), pp.28452852.

10 Majid, R., Demla, V., Mohammed, A.O.M., Friedman, E.R., Kee, P. and Schmitt, K., 2018. Salmonella enteritidis concurrent spinal epidural abscess, urinary tract infection and endocarditis in an immunocompetent host: case report and a review of the literature. J Trop Dis, $6(269)$, p.2.

11 Hakim, S., Davila, F., Amin, M., Hader, I. and Cappell, M.S., 2018. Infectious aortitis: A lifethreatening endovascular complication of nontyphoidal salmonella bacteremia. Case reports in medicine, 2018.

12 Mead, P.S., Slutsker, L., Dietz, V., McCaig, L.F., Bresee, J.S., Shapiro, C., Griffin, P.M. and Tauxe, R.V., 1999. Food-related illness and death in the United States. Emerging infectious diseases, 5(5), p.607.

13 Martin, L.J., Fyfe, M., Doré, K., Buxton, J.A., Pollari, F., Henry, B., Middleton, D., Ahmed, R., Jamieson, F., Ciebin, B. and McEwen, S.A., 2004. Increased burden of illness associated with antimicrobial-resistant Salmonella enterica serotype Typhimurium infections. The Journal of infectious diseases, 189(3), pp.377-384.

14 Helms, M., Simonsen, J. and Mølbak, K., 2004. Quinolone resistance is associated with increased risk of invasive illness and death in Salmonella Typhimurium infection. J Infect Dis, 190, pp.1652-4.

15 Helms, M., Vastrup, P., Gerner-Smidt, P. and Mølbak, K., 2002. Excess mortality associated with antimicrobial drug-resistant Salmonella Typhimurium. Emerging infectious diseases, 8(5), p.490.

16 Holmberg, S.D., Wells, J.G. and Cohen, M.L., 1984. Animal-to-man transmission of antimicrobial-resistant Salmonella: investigations of US outbreaks, 1971-1983. Science, 225(4664), pp.833-835.

17 Boswell, T.C., Coleman, D.J., Purser, N.J. and Cobb, R.A., 1997. Development of quinolone resistance in Salmonella: failure to prevent splenic abscess. The Journal of infection, 34(1), pp.86-87.

18 Mølbak, K., Baggesen, D.L., Aarestrup, F.M., Ebbesen, J.M., Engberg, J., Frydendahl, K., GernerSmidt, P., Petersen, A.M. and Wegener, H.C., 1999. An outbreak of multidrug-resistant, quinolone-resistant Salmonella enterica serotype Typhimurium DT104. New England Journal of Medicine, 341(19), pp.1420-1425.

19 Varma, J.K., Mølbak, K., Barrett, T.J., Beebe, J.L., Jones, T.F., Rabatsky-Ehr, T., Smith, K.E., Vugia, D.J., Chang, H.G.H. and Angulo, F.J., 2005. Antimicrobial-resistant nontyphoidal Salmonella is associated with excess bloodstream infections and hospitalizations. The Journal of infectious diseases, 191(4), pp.554-561.

20 Rai, M. and Carpinella, M.C., 2006. Naturally occurring bioactive compounds. Elsevier.

21 Haruna, A. and Yahaya, S.M., 2021. Recent Advances in the Chemistry of Bioactive Compounds from Plants and Soil Microbes: a Review. Chemistry Africa, pp.1-18.

22 Khan, I., Rahman, H., Abd El-Salam, N.M., Tawab, A., Hussain, A., Khan, T.A., Khan, U.A., Qasim, M., Adnan, M., Azizullah, A. and Murad, W., 2017. Punica granatum peel extracts: HPLC fractionation and LC MS analysis to quest compounds having activity against multidrug resistant bacteria. BMC complementary and alternative medicine, 17(1), pp.1-6. 
23 Papoiu, A.D. and Yosipovitch, G., 2010. Topical capsaicin. The fire of a 'hot'medicine is reignited. Expert opinion on pharmacotherapy, 11(8), pp.1359-1371.

24 Reyes-Escogido, M.D.L., Gonzalez-Mondragon, E.G. and Vazquez-Tzompantzi, E., 2011. Chemical and pharmacological aspects of capsaicin. Molecules, 16(2), pp.1253-1270.

25 Haanpää, M. and Treede, R.D., 2012. Capsaicin for neuropathic pain: linking traditional medicine and molecular biology. European neurology, 68(5), pp.264-275.

26 Narang, N., Jiraungkoorskul, W. and Jamrus, P., 2017. Current understanding of antiobesity property of capsaicin. Pharmacognosy reviews, 11(21), p.23.

27 Omolo, M.A., Wong, Z.Z., Borh, W.G., Hedblom, G.A., Dev, K. and Baumler, D.J., 2018. Comparative analysis of capsaicin in twenty-nine varieties of unexplored Capsicum and its antimicrobial activity against bacterial and fungal pathogens. Journal of Medicinal Plants Research, 12(29), pp.544-556.

28 Marini, E., Magi, G., Mingoia, M., Pugnaloni, A. and Facinelli, B., 2015. Antimicrobial and antivirulence activity of capsaicin against erythromycin-resistant, cell-invasive group A streptococci. Frontiers in microbiology, 6, p.1281.

29 Anogianaki, A., Negrev, N.N., Shaik, Y.B., Castellani, M.L., Frydas, S., Vecchiet, J., Tete, S., Salini, V., De Amicis, D., De Lutiis, M.A. and Conti, F., 2007. Capsaicin: an irritant antiinflammatory compound. Journal of biological regulators and homeostatic agents, 21(1/2), p.1.

30 Cao, S., Chen, H., Xiang, S., Hong, J., Weng, L., Zhu, H. and Liu, Q., 2015. Anti-cancer effects and mechanisms of capsaicin in chili peppers. American Journal of Plant Sciences, 6(19), p.3075.

31 Ayariga, J., Abugri, D.A. and Griffin, G.D., 2021. Capsaicin and Dihydrocapsaicin Extracted from Capsicum chinenses Decrease Cell Viability of Neuroblastoma SH-SY5Y Cells In Vitro.

32 Sun, F., Xiong, S. and Zhu, Z., 2016. Dietary capsaicin protects cardiometabolic organs from dysfunction. Nutrients, 8(5), p.174.

33 Sharma, S.K., Vij, A.S. and Sharma, M., 2013. Mechanisms and clinical uses of capsaicin. European journal of pharmacology, 720(1-3), pp.55-62.

34 Bernal, M.A., Calderon, A.A., Pedreno, M.A., Munoz, R., Ros Barceló, A. and Merino de Caceres, F., 1993. Capsaicin oxidation by peroxidase from Capsicum annuum (variety Annuum) fruits. Journal of Agricultural and Food Chemistry, 41(7), pp.1041-1044.

35 Di Cara, F., Andreoletti, P., Trompier, D., Vejux, A., Bülow, M.H., Sellin, J., Lizard, G., Cherkaoui-Malki, M. and Savary, S., 2019. Peroxisomes in immune response and inflammation. International journal of molecular sciences, 20(16), p.3877.

36 Qiu, J., Niu, X., Wang, J., Xing, Y., Leng, B., Dong, J., Li, H., Luo, M., Zhang, Y., Dai, X. and Luo, Y., 2012. Capsaicin protects mice from community-associated methicillin-resistant Staphylococcus aureus pneumonia. Plos one, 7(3), p.e33032.

37 Chatterjee, S., Asakura, M., Chowdhury, N., Neogi, S.B., Sugimoto, N., Haldar, S., Awasthi, S.P., Hinenoya, A., Aoki, S. and Yamasaki, S., 2010. Capsaicin, a potential inhibitor of cholera toxin production in Vibrio cholerae. FEMS microbiology letters, 306(1), pp.54-60.

38 Das, J., Deka, M. and Gogoi, K., 2018. Antimicrobial Activity of Chilli Extracts (Capsicum chinense) Against Food Borne Pathogens Escherichia coli and Staphylococcus aureus. International Journal of Research and Analytical Reviews (IJRAR), 5(4), pp.717-720.

39 Zeyrek, F.Y. and Oguz, E., 2005. In vitro activity of capsaicin against Helicobacter pylori. Annals of Microbiology, 55(2), pp.125-127.

40 Kar, D., Bandyopadhyay, S., Dimri, U., Mondal, D.B., Nanda, P.K., Das, A.K., Batabyal, S., Dandapat, P. and Bandyopadhyay, S., 2016. Antibacterial effect of silver nanoparticles and 
capsaicin against MDR-ESBL producing Escherichia coli: an in vitro study. Asian Pacific Journal of Tropical Disease, 6(10), pp.807-810.

41 Helms, M., Ethelberg, S., Mølbak, K. and DT104 Study Group, 2005. International Salmonella typhimurium DT104 infections, 1992-2001. Emerging infectious diseases, 11(6), p.859.

42 Herikstad, H., Motarjemi, Y. and Tauxe, R., 2002. Salmonella surveillance: a global survey of public health serotyping. Epidemiology \& Infection, 129(1), pp.1-8.

43 Oyedemi, B.O., Kotsia, E.M., Stapleton, P.D. and Gibbons, S., 2019. Capsaicin and gingerol analogues inhibit the growth of efflux-multidrug resistant bacteria and R-plasmids conjugal transfer. Journal of ethnopharmacology, 245, p.111871.

44 Gloeckner, H., Jonuleit, T. and Lemke, H.D., 2001. Monitoring of cell viability and cell growth in a hollow-fiber bioreactor by use of the dye Alamar Blue ${ }^{\mathrm{TM}}$. Journal of immunological methods, 252(1-2), pp.131-138.

45 Chatterjee, S.N. and Chaudhuri, K., 2012. Gram-negative bacteria: the cell membranes. In Outer membrane vesicles of bacteria (pp. 15-34). Springer, Berlin, Heidelberg.

46 Sharma, N., Phan, H.T., Yoda, T., Shimokawa, N., Vestergaard, M.D.C. and Takagi, M., 2019. Effects of capsaicin on biomimetic membranes. Biomimetics, 4(1), p.17.

47 Magi, G., Marini, E. and Facinelli, B., 2015. Antimicrobial activity of essential oils and carvacrol, and synergy of carvacrol and erythromycin, against clinical, erythromycin-resistant Group A Streptococci. Frontiers in microbiology, 6, p.165.

48 Omolo, M.A., Wong, Z.Z., Mergen, K., Hastings, J.C., Le, N.C., Reil, H.A., Case, K.A. and Baumler, D.J., 2014. Antimicrobial properties of chili peppers. Journal of Infectious Diseases and Therapy.

49 National Center for Biotechnology Information (2022). PubChem Compound Summary for CID 2762649, Ethidium monoazide bromide. Retrieved January 1, 2022 from https://pubchem.ncbi.nlm.nih.gov/compound/Ethidium-monoazide-bromide.

50 Holzer P. (1991). Capsaicin: cellular targets, mechanisms of action, and selectivity for thin sensory neurons. Pharmacological reviews, 43(2), 143-201.

51 Lundbaek, J.A., Birn, P., Tape, S.E., Toombes, G.E., Søgaard, R., Koeppe, R.E., Gruner, S.M., Hansen, A.J. and Andersen, O.S., 2005. Capsaicin regulates voltage-dependent sodium channels by altering lipid bilayer elasticity. Molecular pharmacology, 68(3), pp.680-689.

52 Orlo, E., Russo, C., Nugnes, R., Lavorgna, M. and Isidori, M., 2021. Natural methoxyphenol compounds: Antimicrobial activity against foodborne pathogens and food spoilage bacteria, and role in antioxidant processes. Foods, 10(8), p.1807. 